\title{
MEMORY OF ASALIENT LEARNED SCIENTIST-HYDROGEOLOGIST BELARUS ACADEMICIAN BOGOMOLOV GERASIM VASILYEVICH
}

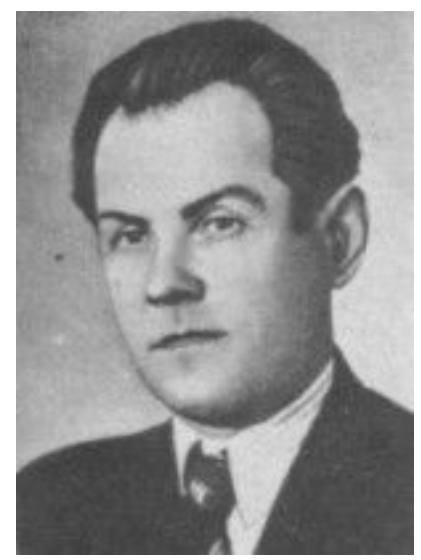

17 м рт 2015 год исполняется 110 лет со дня рождения ер сим сильевич огомолов (1905-1981 гг.) - одного из ведущих гидрогеологов в в ХX столетии.

ер сим сильевич родился в д. лизнево ычевского $\mathrm{p}$ йон моленской обл сти, окончил осковскую горную к демию (1929 г.). 1931 год - 3 меститель директор институт инженерно-строительной гидротехники и гидрогеологии, с 1935 год - директор гидрогеологии и инженерной геологии, 3 тем директор (1939 г.). 1951 год он - 3 меститель министр геологии , с 1954 год 3 меститель к демик -секрет ря отделения геологических и геогр фических н ук . 1960 год ер сим сильевич p бот л в елорусии, где 3 ним л ряд ответственных должностей.

к демик ер сим сильевич огомолов:

- первый в , кто провел опытно-фильтр ционные р боты по определению производительности водоносного горизонт с помощью отк чек (1928-1929 гг., результ ты опубликов ны в 1933 г.);

- первый дек н гидрогеологического ф культет осковского геологоp зведочного институт им. ерго рджоникидзе ( , 1930-1932 гг.);

- первый в , осуществивший водосн бжение крупных н селенных пунктов из межморенных отложений (30-е годы век );

- один из основ телей и первый директор (1939-1950, 1953-1954 гг.) сесоюзного гидрогеологии и инженерной геологии ( );

- первый и единственный в период еликой течественной войны полковник инженерных войск, профессор-гидрогеолог, з меститель н ч льник тыл р сной рмии;

- один из основ телей биолок ции в ( огомолов, евхишвили, очев нов);

- первый в гидрогеолог, з щитивший диссерт цию н соиск ние ученой степени доктор геолого-минер логических н ук не по совокупности н учных трудов (1940 г.), то есть предст вил в ученый совет 3 конченную моногр фию;

- первый з ведующий к федрой гидрогеологии в осковском госуд рственном университете им. . . омоносов (1942-1943 гг.);

- один из второв метод химического з крепления грунтов ( осуд рственн я премия , 1947 г.);

- первый в и единственный н постсоветском простр нстве профессор-гидрогеолог с б зовым обр зов нием, 3 меститель министр геологии (1950-1953 гг.); 
- один из первооткрыв телей к лийных солей в елоруссии ( осуд рственн я премия $\quad, 1952$ г.);

- один из первооткрыв телей подземных вод в еверной фрике и нефти в ндии (1961 г.);

- основ тель и председ тель первого экологического центр в « 3 p ботк н учных основ по предотвр щению з соления почв и водных источников отход ми солигорских к лийных предприятий» (1961-1981 гг.).

- один из первооткрыв телей нефти в елоруссии ( осуд рственн я премия, 1972 г.);

- первый в и единственный н постсоветском простр нстве (до сих пор) почетный президент еждун родной ссоци ции гидрологических н ук (1979 г.).

последние годы в оссии созд н общероссийск я общественн я орг ни3 ция « оссийский союз гидрогеологов» ( осгидрогео, www//rosgidrogeo.com), прогр мм которой вселяет н дежду, что ч яния выд ющихся гидрогеологов

-го столетия будут воплощены в жизнь.

ер сим сильевич проявил р зносторонний т л нт ученого, орг низ тор и руководителя, пед гог (в течение многих лет препод в л в и в елорусском госуд рственном университете). м подготовлено 13 докторов и 33 К ндид т н ук. учн я продукция огомолов предст влен 400 опубликов нными р бот ми, в том числе 12 моногр фиями и 5 учебник ми.

учн я общественность и п ртийно-госуд рственные орг ны высоко оценили деятельность ер сим сильевич .

1947 году з р зр ботку и внедрение в строительство способов искусственного з крепления водон сыщенных песч ных грунтов ему присужден Ст линск я премия. открытие т робинского месторождения к лийных солей — т линск я премия (1952 г.), з открытие и р зведку нефти в елоруссии - осуд рственн я премия. р тные дел он удостоен орден $р$ сной везды и ряд мед лей (1941-1945 гг.); н гр жден орденом рудового р сного н мени и орденом ктябрьской еволюции (1975 г.). менем . . огомолов н зв н одн из улиц в г. олигорске ( ел русь), в 2005 году инсвязи еспублики ел русь ввело в почтовое обр щение м рку «100 лет со дня рождения . . огомолов ».

спомин я н ши неоднокр тные конт кты при проведении р зличных н учных форумов, хочется отметить, что этот нез урядный человек, боевой офицер оветской рмии был исключительно скромным, об ятельным и отзывчивым. кие люди приносили честь и сл ву н шей еликой одине. это созвучно нынешнему 70-летнему юбилею обеды н д ф шизмом.

вторы выр жк ют глубокую призн тельность председ телю оссийского союз гидрогеологов . . огомолову - сыну к демик . . огомолов 3 предост вленные м тери лы о своем отце.

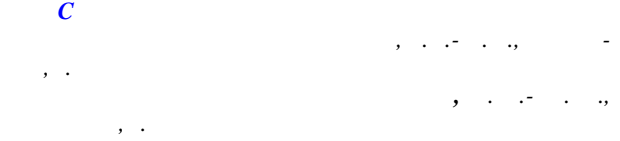

Information about the authors

Karcev A. A., Doctor of Sciences in Geology and Mineralogy, professor, Moscow

Matusevich V. ., Doctor of Sciences in Geology and Mineralogy, professor, Tyumen 